\title{
Performance at high temperature of alkali-activated slag pastes produced with silica fume and rice husk ash based activators
}

\author{
S.A. Bernal ${ }^{\mathrm{a}, \mathrm{b}} \bowtie$, E.D. Rodríguez ${ }^{\mathrm{a}}$, R. Mejía de Gutiérrez ${ }^{\mathrm{a}}$, J.L. Provis ${ }^{\mathrm{b}}$ \\ a. Universidad del Valle (Cali, Colombia) \\ b. University of Sheffield (Sheffield, United Kingdom) \\ $\triangle$ s.bernal@sheffield.ac.uk
}

\author{
Received 2 May 2014 \\ Accepted 22 August 2014 \\ Available on line 24 March 2015
}

\begin{abstract}
This study assessed the mechanical properties, and structural changes induced by high temperature exposure, of alkali-silicate activated slag cements produced with sodium silicates derived from silica fume (SF) and rice husk ash (RHA). Similar reaction products were identified, independent of the type of silicate used, but with subtle differences in the composition of the C-S-H gels, leading to different strength losses after elevated temperature exposure. Cements produced with the alternative activators developed higher compressive strengths than those produced with commercial silicate. All samples retained strengths of more than $50 \mathrm{MPa}$ after exposure to $600^{\circ} \mathrm{C}$, however, after exposure to $800^{\circ} \mathrm{C}$ only the specimens produced with the RHA-based activator retained measurable strength. This study elucidated that silicate-activated slag binders, either activated with commercial silicate solutions or with sodium silicates based on SF or RHA, are stable up to $600^{\circ} \mathrm{C}$.
\end{abstract}

KEYWORDS: Alkali-activated cements; Blast furnace slag; Temperature; Physical properties; Characterisation

Citation/Citar como: Bernal, S.A.; Rodríguez, E.D.; Mejía de Gutiérrez, R.; Provis, J.L. (2015) Performance at high temperature of alkali-activated slag pastes produced with silica fume and rice husk ash based activators. Mater. Construcc. 65 [318], e049 http://dx.doi.org/10.3989/mc.2015.03114.

RESUMEN: Desempeño a temperaturas elevadas de pastas de escoria activada alcalinamente producidas con activadores basados en humo de sílice y ceniza de cascarilla de arroz. Este estudio evaluó las propiedades mecánicas, y cambios estructurales inducidos por exposición a temperaturas elevadas, de cementos de escoria activada alcalinamente producidos con silicatos sódicos derivados de humo de sílice (SF) y ceniza de cascarilla de arroz (RHA). Se identificaron productos de reacción similares, independiente del tipo de silicato utilizado, pero con diferencias menores en la composición de las geles C-S-H, lo cual indujo diferentes pérdidas de resistencia posterior a exposición a temperaturas elevadas. Los cementantes producidos con los activadores alternativos desarrollaron resistencias a la compresión más altas que aquellos producidos con silicato comercial. Todas las muestras retuvieron resistencias de más de $50 \mathrm{MPa}$ posterior a la exposición a $600^{\circ} \mathrm{C}$, sin embargo, posterior a la exposición a $800^{\circ} \mathrm{C}$ únicamente muestras producidas con activadores de RHA retuvieron resistencias medibles. Este estudio elucidó que cementantes de escoria activada con silicatos sódicos, ya sea comerciales o basados en SF o RHA, son estables hasta los $600^{\circ} \mathrm{C}$.

PALABRAS CLAVE: Cementos de activación alcalina; Escoria de alto horno; Temperatura; propiedades físicas; Caracterización

Copyright: (C) 2015 CSIC. This is an open-access article distributed under the terms of the Creative Commons Attribution-Non Commercial (by-nc) Spain 3.0 License. 


\section{INTRODUCTION}

Analysis of the performance of cementitious binders under high temperatures is critical to determine if these materials can preserve their integrity in case of accidental fire, or during exposure to high temperatures during service for materials designed for such applications. In general, exposure to high temperatures leads to severe deterioration and potential collapse of cement-based structures. This is associated with several factors including the increase in steam pressure in the pores with water evaporation, differences in the thermal expansion coefficients of the particles and gels present in the material, and the transformations and dehydration reactions leading to the progressive breakdown of the binding gel $(1,2)$.

Consequently, the materials suffer a dramatic loss of load-bearing capacity, resulting from a significant increase in porosity, with shrinkage and structural cracking (3). In Portland cement based materials, it is well known that the changes taking place at high temperature are induced by dehydration/dehydroxylation of the main hydration products calcium silicate hydrate $(\mathrm{C}-\mathrm{S}-\mathrm{H})$ below $300^{\circ} \mathrm{C}$ and portlandite at temperatures between $400{ }^{\circ} \mathrm{C}$ and $500{ }^{\circ} \mathrm{C}$ (4), which leads to shrinkage of the cement matrix, and its consequent cracking and spalling with the progressive decomposition of these compounds, due to the increased internal stresses generated in this process.

Clinker-free alkali-activated materials produced through the chemical reaction between a highly reactive aluminosilicate source and an alkali-activator $(5,6)$, have been the object of much study over the past decades, as they can develop comparable mechanical properties to Portland cement, when properly formulated and cured $(5,7)$. The properties of these materials are strongly dependent on the nature of the aluminosilicate precursor used (blast furnace slag, fly ash, metakaolin, among others), the type and dose of the alkaline activator, and the curing conditions $(5,7-9)$. This implies that alkaliactivated materials derived from different sources can develop different properties based on the specific conditions of production, curing and testing. However, there is a good consensus that these materials can exhibit advantageous properties such as higher structural and dimensional stablity when exposed to high temperatures, when compared with Portland cement based materials (10-16).

In the specific case of alkali-activated slag, Mejía de Gutiérrez et al. (17) identified that independent of the activator used (either $\mathrm{NaOH}$ or waterglass), alkali activated slag mortars retain a higher compressive strength when exposed to temperatures of up to $600{ }^{\circ} \mathrm{C}$, than Portland cement. Conversely, Guerrieri et al. $(18,19)$ identified that silicateactivated slag concretes exhibit comparable properties to Portland cement and Portland/slag concretes exposed to temperatures of up to $800{ }^{\circ} \mathrm{C}$. This performance was attributed to the higher thermal shrinkage experienced by the alkali-activated slag binder compared with Portland cement, and the differences in the thermal expansion coefficient of the aggregates used in that study (basalt) and the cementitious matrix. Zuda et al. $(20,21)$ evaluated the influence of the type of aggregate in the performance of alkali-activated slag materials, and identified lower reductions in the strength at temperatures above $800{ }^{\circ} \mathrm{C}$ when adding porcelain and quartz aggregate, as a consequence of the thermal stability of these aggregates.

Puertas et al. (11) observed up to $50 \%$ higher retention of compressive strength in alkali-activated slags compared to Portland cements, after exposure to $500{ }^{\circ} \mathrm{C}$. Slight increments in the compressive strength were also identified in samples exposed to $1000{ }^{\circ} \mathrm{C}$. Consistent with these results, Rovnaník et al. (22) also observed reductions in the mechanical strength of silicate-activated slag binders when exposed to temperatures of up to $600{ }^{\circ} \mathrm{C}$, followed by a slight increase in the compressive strength, a significant rise in the flexural strength, and densification of the samples when exposed to higher temperatures.

In order to reduce the embodied energy associated with the alkaline activator required to produce alkaliactivated materials, the feasibility of substituting commercial sodium silicates by alternative silicates produced through the chemical reaction between $\mathrm{NaOH}$, glass wastes and amorphous silica sources such as silica fume and rice husk ash has been studied (23-29). In alkali-activated slag binders (23-25) the development of higher mechanical strengths and reduced permeability has been identified when using activators based on silica fume and $\mathrm{NaOH}$, compared with materials produced with commercial sodium silicates. Similar observations have been identified when using these alternative activators in producing geopolymers based on fly ash (26) and fly ash/slag (27) or metakaolin/slag (28) blends. Even though these materials develop good mechanical strengths and no significant microstructural differences have been observed when compared with binders produced with commercial sodium silicates. It remains unknown whether the use of alternative silicate activators will modify their durability, especially when exposed to high temperatures.

In the present study alkali-activated slag binders produced with a commercial sodium silicate, and silicate solutions produced via chemical reaction of silica fume or rice husk ash with $\mathrm{NaOH}$, are exposed to temperatures of up to $1000^{\circ} \mathrm{C}$. Compressive strength and mass loss are determined at the different temperatures of exposure, and characterisation of thermally treated binders is carried out via X-ray diffraction, thermogravimetry and Fourier transform infrared spectroscopy. 


\section{EXPERIMENTAL METHODS}

\subsection{Materials}

The primary raw material used in this study is a highly amorphous granulated blast furnace slag (GBFS) from the Colombian factory Acerías Paz del Río, with a specific gravity of $2900 \mathrm{~kg} / \mathrm{m}^{3}$ and a Blaine fineness of $399 \mathrm{~m}^{2} / \mathrm{kg}$. The particle size range determined through laser diffraction is $0.1-74 \mu \mathrm{m}$, with a $\mathrm{d}_{50}$ of $15 \mu \mathrm{m}$. The chemical composition of the GBFS is shown in Table 1.

Alkali activation of this precursor was carried out using three different activators:

- A commercial sodium silicate (WG) solution with a chemical composition of 32.4 mass $\%$ $\mathrm{SiO}_{2}, 13.5$ mass $\% \mathrm{Na}_{2} \mathrm{O}$ and 54.1 mass $\%$ water, and a solution modulus $\left(\mathrm{Ms}=\mathrm{SiO}_{2} / \mathrm{Na}_{2} \mathrm{O}\right.$ molar ratio) of 2.4.

- An alkali silica fume activator (SFA) prepared with a commercial densified silica fume (Sikafume), containing 95.51 mass $\% \mathrm{SiO}_{2}$, analytical grade $\mathrm{NaOH}$ and tap water, blended to obtain the desired molar ratios corresponding to the WG-based activators. The water, SF and $\mathrm{NaOH}$ were mixed for $10 \mathrm{~min}$, and sealed in plastic containers immersed in a water bath at $25^{\circ} \mathrm{C}$ for $24 \mathrm{~h}$ before use, to allow the silica fume particles time to dissolve before mixing with the aluminosilicate components.

- An alkali rice husk ash activator (RHAA) prepared with a rice husk ash and analytical grade $\mathrm{NaOH}$. The RHA was produced by burning rice husks at $600{ }^{\circ} \mathrm{C}$ in air in a laboratory furnace for $2 \mathrm{~h}$, and ground in a ball mill to obtain a particle size distribution between 1 and $60 \mu \mathrm{m}$ with a $\mathrm{d}_{50}$ of $9.2 \mu \mathrm{m}$. These conditions have been determined in a previous study as being suitable to obtain a highly reactive pozzolan from this particular source of rice husks (30). The content of amorphous silica in the final RHA was $68 \%$, with an unburnt carbon content of less than $2 \%$. The RHA and $\mathrm{NaOH}$ were mixed under the same conditions mentioned above for SFA, considering only the content of reactive (amorphous) silica in the RHA in calculating compositions.

\subsection{Sample preparation and tests conducted}

Alkali-activated slag pastes were formulated with an activator dose of $5 \mathrm{~g} \mathrm{Na}_{2} \mathrm{O}$ per $100 \mathrm{~g}$ slag, and a water to binder (free water + water in the activator)/ (anhydrous activator + slag) ratio of 0.23 . The paste was cast in cylindrical molds of $30 \mathrm{~mm}$ diameter $\times 60 \mathrm{~mm}$ height, sealed, and cured under ambient conditions (temperature $25{ }^{\circ} \mathrm{C}$ and relative humidity $75 \%$ ) for $24 \mathrm{~h}$. Subsequently, the cylinders were demolded and cured in a humidity chamber at a temperature of $27 \pm 2{ }^{\circ} \mathrm{C}$ and relative humidity (RH) $>90 \%$, for 28 days.

For analysis of thermal performance, 28-day cured specimens were then held for $24 \mathrm{~h}$ at $50^{\circ} \mathrm{C}$ to remove the excess superficial water, and heated in a furnace at temperatures of 200,400,600, 800 and $1000{ }^{\circ} \mathrm{C}$, with a heating rate of $1^{\circ} \mathrm{C} / \mathrm{min}$ and a hold time of $2 \mathrm{~h}$, and then cooled inside the furnace to $25^{\circ} \mathrm{C}$ to avoid thermal shock and potential cracking of the samples. After thermal exposure, compressive strength was determined using a universal testing instrument (ELE International) at a displacement rate of $1 \mathrm{~mm} / \mathrm{min}$. Changes in the mass of the specimens were also determined.

Structural characterization of the heated pastes was conducted through X-ray diffraction using a RX Rigaku R-INT 2200 diffractometer. Fourier transform infrared (FTIR) spectroscopy was conducted via the $\mathrm{KBr}$ pellet technique, using a Shimadzu FTIR 8400 instrument, scanning from 2000 to $400 \mathrm{~cm}^{-1}$, and thermogravimetry was carried out in a SDT-Q600 instrument in a nitrogen atmosphere, from 25 to $1100{ }^{\circ} \mathrm{C}$ at a heating rate of $10{ }^{\circ} \mathrm{C} / \mathrm{min}$.

\section{RESULTS AND DISCUSSION}

\subsection{Compressive strength}

Compressive strengths higher than $40 \mathrm{MPa}$ are identified (Figure 1) for all the pastes after 7 days of curing. At both times of curing assessed, 7 and 28 days, increased mechanical strengths are identified when using the alternative activators based on SF and RHA compared with the strengths developed when using a commercial silicate solution. These differences are more significant at 28 days, where slags activated with a SF and RHA-based activators developed compressive strengths above $100 \mathrm{MPa}$. In a previous study activating metakaolin/ slag blends with similar alternative activators (28), it was suggested that when using SFA and RHAA it is likely that at early age the mechanism of activation is dominated by the different rates of release of silicate in these systems, which influences the structural characteristics of the binders and therefore

TABLE 1. Chemical composition of the granulated blast furnace slag used, from $\mathrm{X}$-ray fluorescence analysis. LOI is loss on ignition at $1000^{\circ} \mathrm{C}$

\begin{tabular}{lccccccccc}
\hline Component & $\mathbf{S i O}_{2}$ & $\mathbf{A l}_{2} \mathbf{O}_{3}$ & $\mathbf{C a O}$ & $\mathbf{F e}_{2} \mathbf{O}_{3}$ & $\mathbf{M g O}$ & $\mathbf{T i O}_{2}$ & $\mathbf{N a}_{2} \mathbf{O}$ & Others & $\mathbf{L O I}$ \\
\hline Mass $\%$ as oxide & 33.7 & 12.8 & 45.4 & 1.0 & 1.0 & 0.5 & 0.1 & 2.8 & 2.7 \\
\hline
\end{tabular}




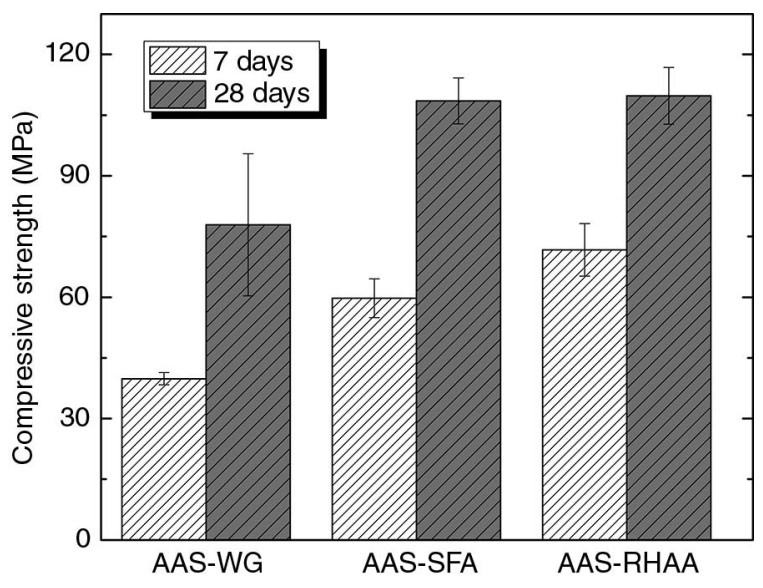

FIgURE 1. Compressive strength of slag pastes activated with different silicate solutions.

their mechanical performance. The results of this study are also consistent with the higher mechanical strengths observed in fly ash geopolymer systems (26) and alkali-activated slag/fly ash binders (27) when using alternative activators based on SF and RHA, respectively.

Compressive strength values of 28-day cured pastes exposed to temperatures between $200{ }^{\circ} \mathrm{C}$ and $800{ }^{\circ} \mathrm{C}$ are shown in Figure 2. Exposure to $200^{\circ} \mathrm{C}$ seems to promote a slight increase in the compressive strength values when compared with the nonexposed specimens (Figure 1) of all the pastes, independently of the type of silicate activator used. Conversely, exposure at $400{ }^{\circ} \mathrm{C}$ led to a significant reduction of the mechanical strength (up to $50 \%$ lower when compared with non-exposed samples), especially of slag pastes activated with SF and RHAbased activators. However, it is important to note that the pastes still retain compressive strengths of up to $65 \mathrm{MPa}$ and $52 \mathrm{MPa}$, when activated with SF

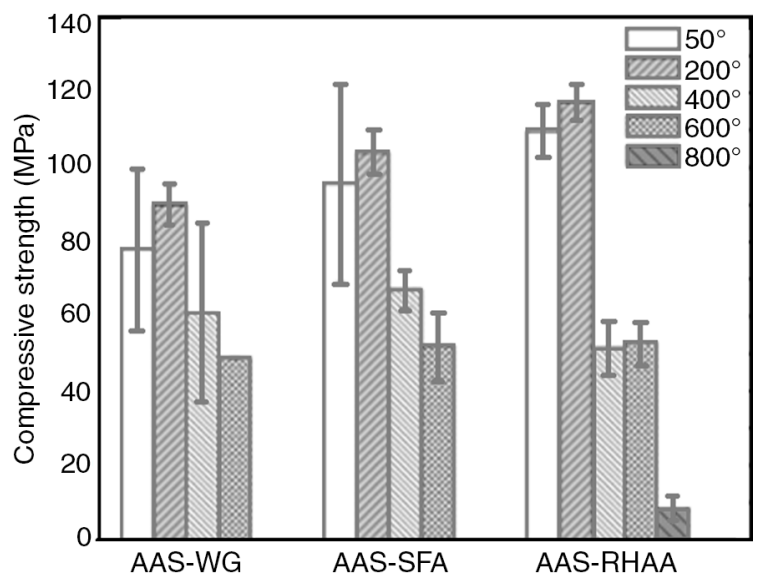

FIGURE 2. Compressive strength of activated slag exposed to high temperatures as a function of the silicate activator source. and RHA-based activators respectively, after exposure to this temperature.

These values are substantially higher than those obtained in alkali-activated metakaolin/slag blended pastes (13), where exposure to $400{ }^{\circ} \mathrm{C}$ reduced the compressive strength by $87 \%$ compared with nonexposed samples. In this case, the reduction in the compressive strength is consistent with the temperature of dehydration of C-S-H type gels $(4,13,22)$, which is the main reaction product responsible for the mechanical performance of alkali-activated slag binders. As the water in this phase is more tightly bonded to the gel structure than in geopolymer binders forming in the metakaolin/slag activated samples (13), higher temperatures of exposure are required to promote the complete dehydration of the C-S-H type gel, and the consequent destruction of the binding matrix. The alkali-activated slag samples exposed to $600{ }^{\circ} \mathrm{C}$ retain mechanical strengths slightly lower than specimens exposed to $400^{\circ} \mathrm{C}$, but still around $50 \mathrm{MPa}$.

The compressive strengths of samples activated with WG and SFA activators exposed to $800^{\circ} \mathrm{C}$ and $1000{ }^{\circ} \mathrm{C}$ could not be determined, as the samples were easily crumbled by hand. This is consistent with the high volumetric contraction that can take place between $600^{\circ} \mathrm{C}$ and $1000^{\circ} \mathrm{C}$ in alkali-activated pastes (13) inducing the severe macrocracking of the specimens. Pastes activated with RHA-based activators showed macrocracks after $600{ }^{\circ} \mathrm{C}$ and dimensional changes at $800{ }^{\circ} \mathrm{C}$ and $1000{ }^{\circ} \mathrm{C}$; however, the samples exposed at $800{ }^{\circ} \mathrm{C}$ do not exhibit the same level of decay (Figure 3) observed in specimens activated with WG and SFA, and report a residual strength of $5 \mathrm{MPa}$. This indicates that using the RHAA activator seems to enhance the strength retention upon heating of alkali-activated slag binders.

\subsection{X-ray diffraction (XRD)}

The X-ray diffractograms of the silicate-activated slag binders after 28 days of curing and exposed to $800^{\circ} \mathrm{C}$ and $1000{ }^{\circ} \mathrm{C}$ are shown in Figure 4. In all the activated samples assessed, the formation of the crystalline phase gismondine $\left(\mathrm{CaAl}_{2} \mathrm{Si}_{2} \mathrm{O}_{8} \cdot 4 \mathrm{H}_{2} \mathrm{O}, \mathrm{PDF}\right.$ \# $020-0452$ ), and a partially ordered calcium silicate hydrate $(\mathrm{C}-\mathrm{S}-\mathrm{H})$ type phase with a riversideite $9 \AA$ type structure $\left(\mathrm{Ca}_{5} \mathrm{Si}_{6} \mathrm{O}_{17} \cdot \mathrm{H}_{2} \mathrm{O}\right.$, PDF \# 029-0329, but probably with some $\mathrm{Al}$ substitution), is identified. This indicates that the sodium silicates produced with SF and RHA do not modify the phase assemblage of alkali-activated slag binders compared to the WG activator, as the reaction products forming in these systems are consistent with what has been observed in previous studies using a slag from the same source $(8,31)$. Traces of gehlenite $\left(\mathrm{Ca}_{2} \mathrm{Al}_{2} \mathrm{SiO}_{7}, \mathrm{PDF} \#\right.$ 035-0755), calcite $\left(\mathrm{CaCO}_{3}, \mathrm{PDF}\right.$ \# 01-083-0577) and quartz ( $\mathrm{SiO}_{2}, \mathrm{PDF} \#$ 046-1045) 


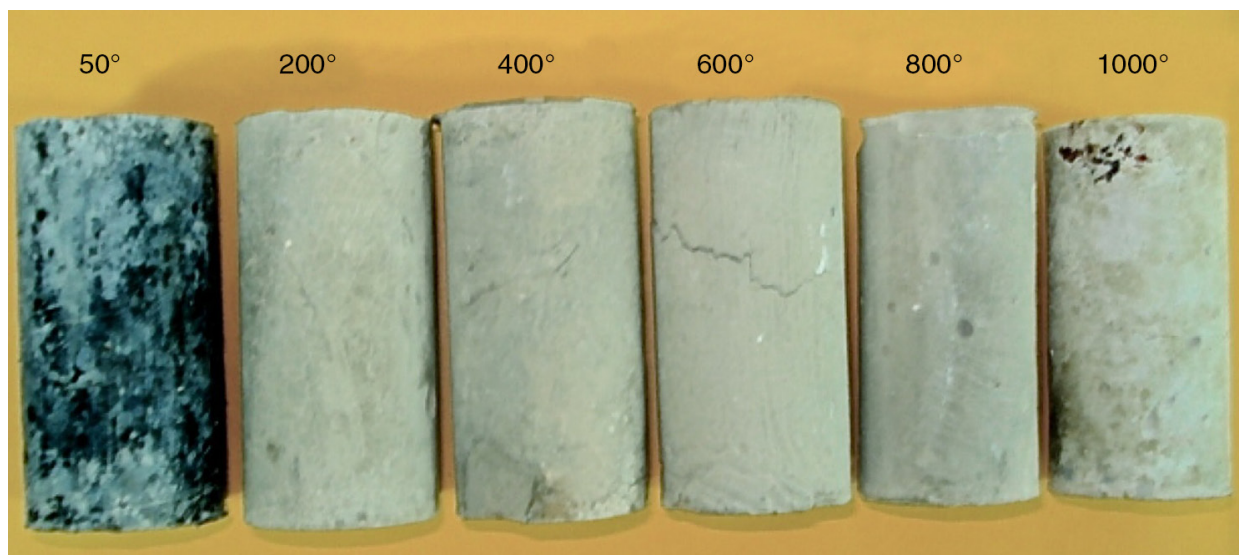

FIGURE 3. Photograph of RHAA-activated slag specimens exposed to different temperatures. The green colour of the sample treated at $50{ }^{\circ} \mathrm{C}$ is intrinsic to the slag-rich binder, and converts to white upon heating due to oxidation processes. The cracks in samples heated above $600^{\circ} \mathrm{C}$ are clearly visible.

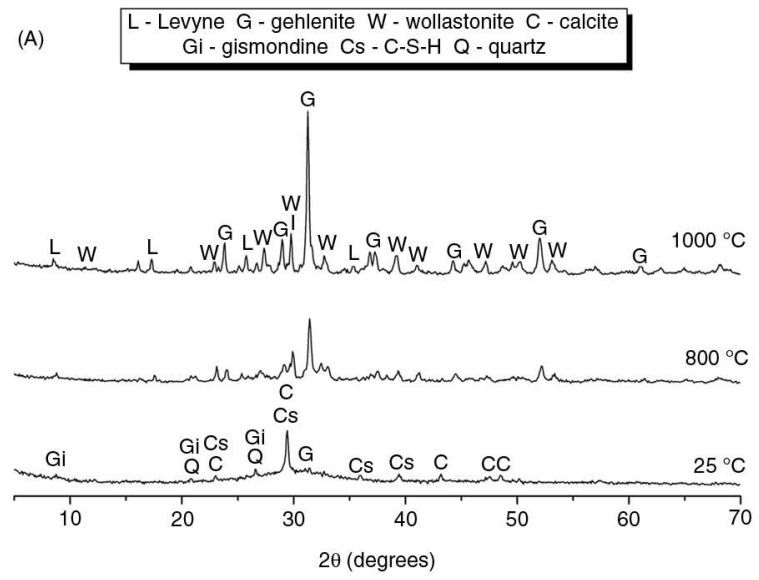

(B)

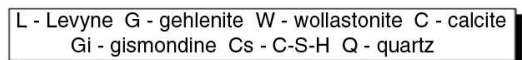

G
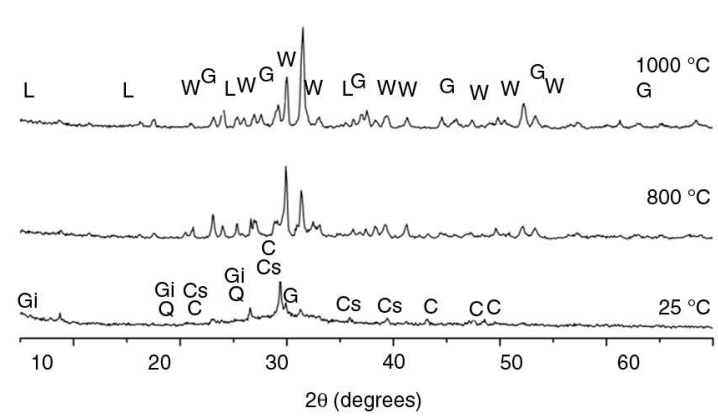

(C)

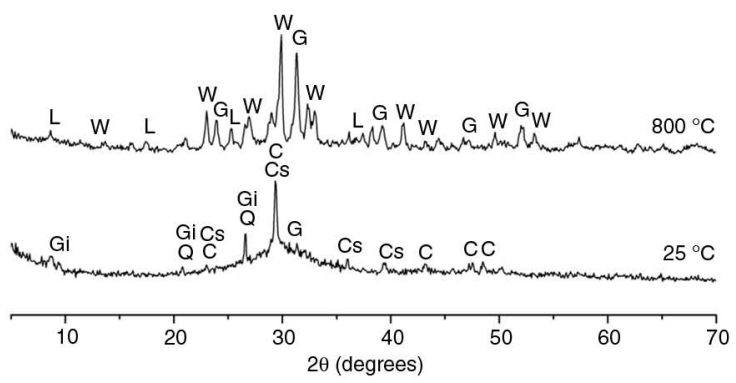

FIGURE 4. X-ray diffractograms of alkali-activated slag pastes activated with (A) commercial sodium silicate, (B) silica fume based activator and (C) rice husk ash based activator, as function of the temperature of exposure.

are also observed. These compounds have been identified in the unreacted slag (8), and calcite and quartz do not seem to participate in the activation reaction.

Upon exposure to $800^{\circ} \mathrm{C}$, a significant reduction in the intensity of the main reflection peak assigned to the C-S-H type phase $\left(29.4^{\circ} 2 \theta\right)$ is observed in all the activated pastes, along with a significant increase in the intensity of the peaks assigned to gehlenite, which is likely to result from partial devitrification of the remnant slag grains in the specimens. The crystalline phase wollastonite- $2 \mathrm{M}\left(\mathrm{CaSiO}_{3}, \mathrm{PDF} \#\right.$ 027-0088), a dehydration product of C-S-H type 
gels, and traces of what seems to be a dehydrated form of the zeolite levyne, are also observed in all the samples. It is important to note that the intensities of the reflections assigned to wollastonite are significantly higher in specimens activated with RHA-based activator compared with binders produced with WG and SFA activators, indicating that the fraction of C-S-H forming in RHA-activated slag binders might be much higher in this binders compared with pastes produced with the other activators used.

In alkali silicate-activated slag binders, Puertas (11) identified the formation of åkermanite, gehlenite and nepheline after exposure to $1200{ }^{\circ} \mathrm{C}$, while Rovnaník et al. (22) identified formation of åkermanite, diopside and wollastonite at temperatures of exposure $>800{ }^{\circ} \mathrm{C}$. On the other hand, Rashad et al. (16) observed the formation of åkermanite, merwinite and gehlenite in sulfate-activated slag samples after exposure to $800{ }^{\circ} \mathrm{C}$. The slag used here has a very low $\mathrm{Mg}$ content compared to the materials used in those studies, and so gehlenite forms in preference to these other Mg-rich phases during its partial devitrification.

\subsection{Thermogravimetry (TG)}

The total mass loss values of AAS-WG, AAS-SFA and AAS-RHA (Figure 5) samples upon heating to $1100{ }^{\circ} \mathrm{C}$ were all $22 \pm 2 \%$, indicating that the commercial and alternative activators are promoting the formation of similar amounts of reaction products upon the activation of the slag. The thermograms of pastes show that the mass loss occurs in two stages: the first one between 37 and $600{ }^{\circ} \mathrm{C}$, where the major loss $(18 \%)$ occurs between $37^{\circ} \mathrm{C}$ and $260^{\circ} \mathrm{C}$, associated with the evaporation of the free water, and the loss of water molecules leading to dehydration of the C-S-H type gel present in the alkali-activated slag binders. The second stage is identified around 600 to $800{ }^{\circ} \mathrm{C}$ attributed to the decomposition of carbonates (4). In this temperature range, it is also likely that there is some crystallisation of the poorly ordered component present in these binders, most likely leading to wollastonite formation, which occurs at $\sim 780^{\circ} \mathrm{C}$ (32), as this is the main crystalline phase identified via XRD (Figure 5) in these samples exposed above $800{ }^{\circ} \mathrm{C}$.

After exposure of the binders to $800^{\circ} \mathrm{C}$, the mass loss below $300{ }^{\circ} \mathrm{C}$ is no longer identified in any of the silicate-activated slag pastes, consistent with the complete removal of the free water and the chemically/adsorbed water in the reaction products during thermal treatment. The only feature identifiable in the thermograms is a peak at $664{ }^{\circ} \mathrm{C}$, consistent with the decomposition of the residual carbonaterich compounds present in these samples, including those which result from some minor $\mathrm{CO}_{2}$ uptake onto the products between temperature exposure and TG analysis. Similar results are observed for the specimens after exposure to $1000{ }^{\circ} \mathrm{C}$, where minor traces of decomposition of carbonates are again identified.

It is also notable that in the carbonate region between 600 to $800{ }^{\circ} \mathrm{C}$, the $50{ }^{\circ} \mathrm{C}$ samples show two peaks whereas the heated samples show only one; this aids in the identification of the lower-temperature peak at $\sim 660{ }^{\circ} \mathrm{C}$ to the products of atmospheric $\mathrm{CO}_{2}$
(A)
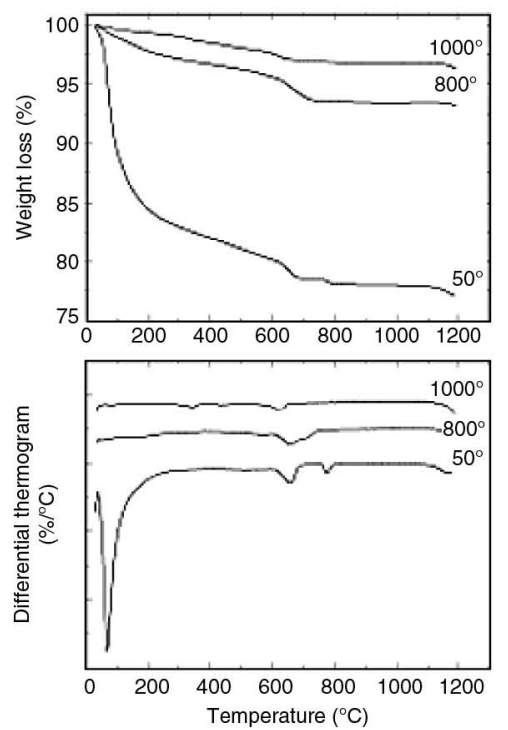
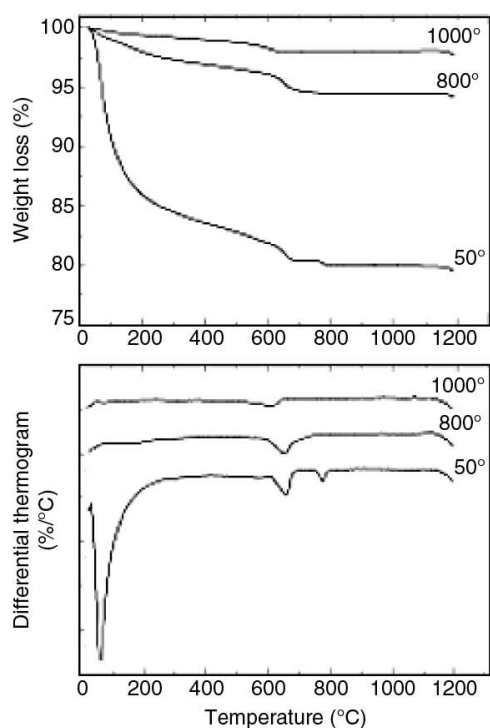

(C)
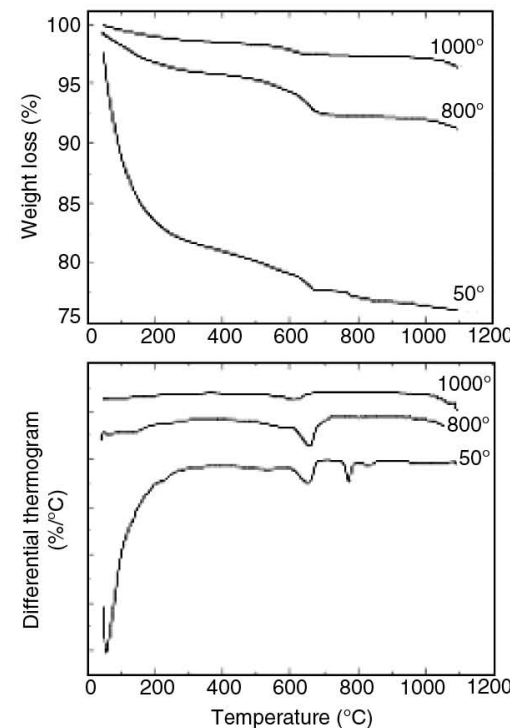

FIGURE 5. Thermograms (top) and differential thermograms (bottom) of alkali-activated slag pastes activated with (A) commercial sodium silicate, (B) silica fume-based activator and (C) rice husk ash-based activator, as a function of the temperature of exposure. 
uptake by the binder and/or its pore solution, while the sharp higher-temperature peak $\left(\sim 760{ }^{\circ} \mathrm{C}\right)$ is related to the more highly crystalline calcite present in the slag due to its weathering prior to binder production, which is decarbonated during thermal exposure and does not rapidly re-form under atmospheric conditions.

\subsection{Fourier Transform Infrared (FTIR) Spectroscopy}

Figure 6 shows the FTIR spectra of the different silicate-activated slag binders as a function of the temperature of exposure. In 28-day cured samples before high temperature exposure, a high intensity broad band assigned to the stretching vibration modes of $\mathrm{H}-\mathrm{OH}$ groups (between 3200 and $3600 \mathrm{~cm}^{-1}$ ) in the hydrated reaction products is identified. A small vibration band observed at $\sim 1640 \mathrm{~cm}^{-1}$ corresponds to the bending vibration modes of $\mathrm{H}-\mathrm{OH}$ bonds, while the band between $1200-950 \mathrm{~cm}^{-1}$ is associated with the asymmetric stretching vibration mode of Si-O-T bonds (T: tetrahedral Si or Al) $(33,34)$. The shoulder at $875 \mathrm{~cm}^{-1}$ is assigned to the asymmetric stretching of $\mathrm{AlO}_{4}$ groups present in the binders $(35,36)$. Traces of carbonates are also identified at $1480 \mathrm{~cm}^{-1}$, assigned to the asymmetric stretching mode of the O-C-O bonds of $\mathrm{CO}_{3}^{2-}$ groups (37). The band at $\sim 660 \mathrm{~cm}^{-1}$ is assigned to Si-O-Si bending vibration modes, and vibrations between $400-500 \mathrm{~cm}^{-1}$ correspond to the deformation of $\mathrm{SiO}_{4}$ tetrahedra (34).

Upon exposure to high temperatures, the intensity of the broad band assigned to the stretching vibration modes of $\mathrm{H}-\mathrm{OH}$ groups decreases
(A)

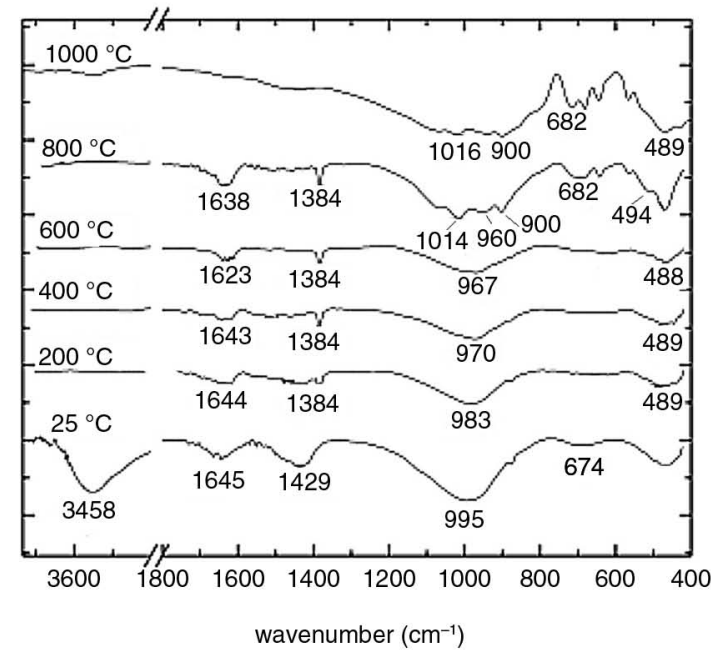

(B)

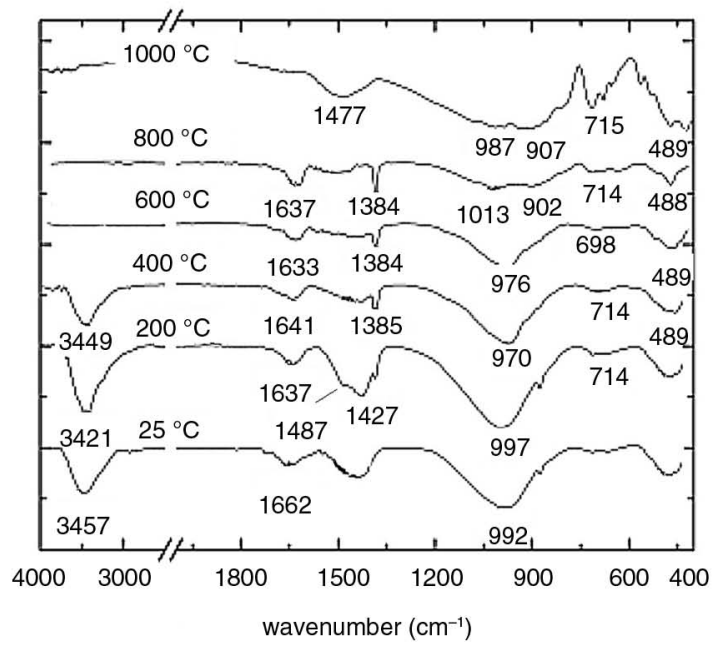

(C)

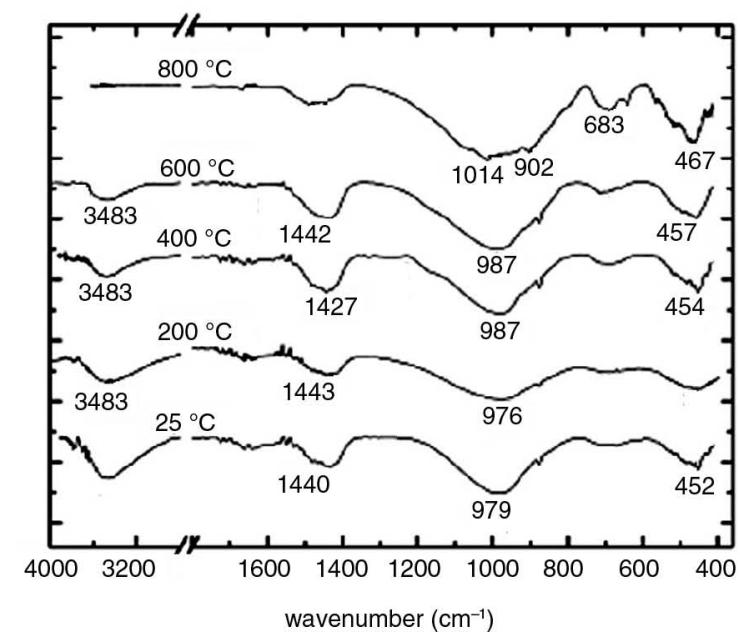

FIGURE 6. Fourier transform infrared spectra of alkali-activated slag pastes activated with (A) commercial sodium silicate, (B) silica fume based activator, and (C) rice husk ash based activator, as a function of the temperature of exposure. 
(Figure 6). In the case of binders activated with the commercial silicate, this band is no longer observed after exposure to $200^{\circ} \mathrm{C}$. Conversely, in specimens activated with SFA and RHAA, this band is still identified in pastes exposed to temperatures as high as $400{ }^{\circ} \mathrm{C}$ and $600{ }^{\circ} \mathrm{C}$ respectively. This might suggest that the water in the reaction products forming when using the SF and RHA based activators is more tightly bonded than when using commercial sodium silicate, as higher temperatures of exposure are required for its complete removal from the paste. This could be a potential consequence of a denser microstructure of the binding phases forming when using the alternative activators produced.

In WG and SFA activated specimens exposed to temperatures between $200{ }^{\circ} \mathrm{C}$ and $800{ }^{\circ} \mathrm{C}$ the formation of a distinctive peak centred at $1384 \mathrm{~cm}^{-1}$ is identified. It is well known that zeolites can separate $\mathrm{CO}_{2}$ from gas mixtures and can be good candidates for $\mathrm{CO}_{2}$ capture, especially at moderate temperatures $\left(120^{\circ} \mathrm{C}-400{ }^{\circ} \mathrm{C}\right)(38)$. Stevens et al. (39) assigned this peak to bidentate carbonate sites associated with chemisorbed $\mathrm{CO}_{2}$ in zeolites, whose intensity increased with the temperature at which $\mathrm{CO}_{2}$ sorption took place. Considering that the formation of gismondine has been identified in these binders (Figure 4), it is likely that some absorption of $\mathrm{CO}_{2}$ is occurring during testing, and as the exposure to high temperatures leads to the decarbonation of the samples, the consequent reduction in the intensity of the broad band at $1420-1440 \mathrm{~cm}^{-1}$ allows the identification of this phase. In specimens produced with RHA the peak at $1384 \mathrm{~cm}^{-1}$ is not clearly identified, as this peak overlaps with the resonance of the O-C-O bonds whose intensity does not decrease upon high temperature exposure.

The spectra in Figure 6 do show differences in the main bands in the ranges of $600-400 \mathrm{~cm}^{-1}$ and $1000-900 \mathrm{~cm}^{-1}$ as a function of the activator used and the temperature of exposure. In the WG-activated slag paste (Figure 6A), this band is centred at $995 \mathrm{~cm}^{-1}$ after 28 days of curing. Upon exposure to temperatures up to $600{ }^{\circ} \mathrm{C}$ this band shifts towards lower wavenumbers. This is likely associated with the depolymerization of the C-A-S-H product, promoting the formation of a less crosslinked reaction product upon heating. In the specimen exposed to 800 and $1000{ }^{\circ} \mathrm{C}$ the formation of bands at 1016, 960 and $900 \mathrm{~cm}^{-1}$ is observed, assigned to the triply degenerate antisymmetric stretch of the $\mathrm{SiO}_{4}$ present in wollastonite (40), as identified in the X-ray diffractogram (Figure 4). The bands observed at 723 and $446 \mathrm{~cm}^{-1}$ are assigned to the $\mathrm{CaO}_{6}$ sites present in wollastonite.

In the paste activated with the silica fume based activator (Figure 6B) the T-O-T band is observed at $992 \mathrm{~cm}^{-1}$ after 28 days of curing. Upon heating the vibration mode shifted towards lower wavenumbers, similar to the commercial silicate activated slag binders. This is consistent with the fact that similar reaction products have been identified in both systems through X-ray diffraction (Figure 4) and thermogravimetry (Figure 5). In samples exposed to 800 and $1000{ }^{\circ} \mathrm{C}$, vibrations bands assigned to the formation of wollastonite are also observed; however, these modes seem broader than in the commercial silicate activated paste, which suggests a lower degree of ordering in the structure of the wollastonite formed through decomposition of the $\mathrm{C}-\mathrm{S}-\mathrm{H}$ type gel in this formulation.

Conversely to the changes identified in the samples activated by WG and SFA, changes in the wavenumber of the T-O-T band are not identified when the RHAA specimens are heated to $200{ }^{\circ} \mathrm{C}$. In samples exposed to $400{ }^{\circ} \mathrm{C}$, a slight shift in the vibration mode of the T-O-T band towards higher wavenumbers (from $976 \mathrm{~cm}^{-1}$ to $987 \mathrm{~cm}^{-1}$ ) is observed, when compared with specimens heated up to $200{ }^{\circ} \mathrm{C}$. No further changes in the position of this band are observed when the sample is exposed to $600{ }^{\circ} \mathrm{C}$. This indicates that the exposure to high temperature of slag activated with RHAA induced less disruptions in the C-S-H formed in these binders than in the others tested, and it is most likely promoting the densification of this phase between $400{ }^{\circ} \mathrm{C}$ and $600{ }^{\circ} \mathrm{C}$. This is consistent with the fact that the same compressive strength was retained in the RHAA samples exposed to these two temperatures (Figure 1). In samples exposed to $800^{\circ} \mathrm{C}$, however, similar results to those identified in samples activated by WG and SFA are observed, in agreement with the formation of wollastonite in all of the samples (Figure 4C).

These FTIR results elucidate that, even though other techniques seem to show that similar reaction products are forming in the activated slag pastes with all three activators, the exposure to high temperature induced different changes in the main binding phase forming in these materials. This demonstrates that there might be significant differences in the nano-porosity and chemical composition of the C-S-H type gel, depending on the silicate activator used, as consequence of the variable availability of $\mathrm{Si}$ at different times of reaction. This directly influences the degree of water release and the consequent shrinkage of this type of gel upon high temperature exposure. Therefore, further investigation in this area is required.

\section{CONCLUSIONS}

This study demonstrates that it is feasible to produce alkali-activated slag binders using silicate based alkaline activators derived from the chemical reaction between $\mathrm{NaOH}$ and silica fume and rice husk ash. Binders produced with silica fume and rice husk ash based activators developed higher compressive strength $(\geq 100 \mathrm{MPa}$ at 28 days of curing) 
than those produced with commercial sodium silicate, although similar reaction products, mainly C-S-H and gismondine, are forming in all the binders. Slight differences in the chemistry of the C-S-H type binding gel are identified when using the silica fume and rice husk ash based activators, which is likely associated with the rate of availability of silicate species in these systems, which consequently modifies the performance of the binders. This elucidates that using silica fume and rice husk ash as precursors to produce sodium silicate activators can be an effective pathway to enhance the compressive strength of alkali-activated slag materials, without requiring any increase in the activator dose in the formulation of these binders.

Upon high temperature exposure, it is possible to observe the formation of gehlenite, likely as a result of the partial devitrification of the remnant slag grains in the specimens, along with wollastonite, a dehydration product of C-S-H type gel, and a dehydrated form of levyne. The slight differences in the C-S-H type gel seem to modify the degree of loss of strength under elevated temperature exposure, as function of the type of activator used, so that all the binders retain strengths of more than $50 \mathrm{MPa}$ after exposure to $600{ }^{\circ} \mathrm{C}$, while only the RHA-based system retains measurable strength at $800{ }^{\circ} \mathrm{C}$. For the particular case of sodium silicate activators derived from rice husk ash, in addition to the superior performance of activated slag binders exposed to high temperatures when compared with the other silicates assessed in this study, there are environmental benefits associated with use of this material, which is an industrial waste that is widely available in many parts of the world, and which in some cases cannot be successfully used as a supplementary cementitious material for producing blended Portland cement products.

\section{ACKNOWLEDGMENTS}

This study was sponsored by the Universidad del Valle (Colombia), Centro de Excelencia de Nuevos Materiales (CENM) and Departamento Administrativo de Ciencia, Tecnología e Innovación, Colciencias. The participation of JLP and SAB received funding from the Faculty of Engineering, University of Sheffield.

\section{REFERENCES}

1. Delhomme, F.; Ambroise, J.; Limam, A. (2012) Effects of high temperatures on mortar specimens containing Portland cement and GGBFS. Mater. Struct. 45 [11], 1685-1692. http://dx.doi.org/10.1617/s11527-012-9865-7.

2. Matesová, D.; Bonen, D.; Shah, S.P. (2006) Factors affecting the resistance of cementitious materials at high temperatures and medium heating rates. Mater. Struct. 39 [9], 919-935. http://dx.doi.org/10.1617/s11527-006-9198-5

3. Handoo, S.K.; Agarwal, S.; Agarwal, S.K. (2002) Physicochemical, mineralogical, and morphological characteristics of concrete exposed to elevated temperatures. Cem. Concr. Res. 32, 1009-1018. http://dx.doi.org/10.1016/S0008-8846 (01)00736-0.

4. Alarcon-Ruíz, L.; Platret, G.; Massieu, E.; Ehrlacher, A. (2005) The use of thermal analysis in assessing the effect of temperature on a cement paste. Cem. Concr. Res. 35, 609-613. http://dx.doi.org/10.1016/j.cemconres.2004.06.015.

5. Provis, J.L. (2014) Geopolymers and other alkali activated materials: why, how, and what? Mater. Struct. 47, 11-25. http://dx.doi.org/10.1617/s11527-013-0211-5.

6. Juenger, M.C.G.; Winnefeld, F.; Provis, J.L.; Ideker, J. (2011) Advances in alternative cementitious binders. Cem. Concr. Res. 41, 1232-1243. http://dx.doi.org/10.1016/j.cemconres. 2010.11.012.

7. Provis, J.L.; Bernal, S.A. (2014) Geopolymers and related alkali-activated materials. Annu. Rev. Mater. Res. 44,299-327. http://dx.doi.org/10.1146/annurev-matsci-070813-113515.

8. Bernal, S.A.; San Nicolas, R.; Myers, R.J.; Mejía de Gutiérrez, R.; Puertas, F.; van Deventer, J.S.J.; Provis, J.L. (2014) $\mathrm{MgO}$ content of slag controls phase evolution and structural changes induced by accelerated carbonation in alkali-activated binders. Cem. Concr. Res. 57, 33-43. http:// dx.doi.org/10.1016/j.cemconres.2013.12.003.

9. Palomo, A.; Krivenko, P.; Garcia-Lodeiro, I.; Kavalerova, E.; Maltseva, O.; Fernández-Jiménez, A. (2014) A review on alkaline activation: new analytical perspectives. Mater. Construcc. 64 [315]. http://dx.doi.org/10.3989/mc.2014. 00314 .

10. Guerrieri, M.; Sanjayan, J.G. (2010) Behavior of combined fly ash/slag-based geopolymers when exposed to high temperatures. Fire Mater. 34 [4], 163-175. http://dx.doi.org/ 10.1002/fam.1014.

11. Puertas, F.; Gil-Maroto, A.; Palacios, M.; Amat, T. (2006) Alkali-activated slag mortars reinforced with AR glassfibre. Performance and properties. Mater. Construcc. 56 [283], 79-90. http://dx.doi.org/10.3989/mc.2006.v56.i283.10.

12. Kong, D.L.Y.; Sanjayan, J.G. (2010) Effect of elevated temperatures on geopolymer paste, mortar and concrete. Cem. Concr. Res. 40, 334-339. http://dx.doi.org/10.1016/j. cemconres.2009.10.017.

13. Bernal, S.A.; Rodríguez, E.D.; Mejía de Gutierrez, R.; Gordillo, M.; Provis, J.L. (2011) Mechanical and thermal characterisation of geopolymers based on silicate-activated metakaolin/slag blends. J. Mater. Sci. 46, 5477-5486. http://dx.doi.org/10.1007/s10853-011-5490-z.

14. Bernal, S.A.; Mejía de Gutiérrez, R.; Ruiz, F.; Quiñones, H.; Provis, J.L. (2012) High-temperature performance of mortars and concretes based on alkali-activated slag/ metakaolin blends. Mater. Constr. 62, 471-488. http:// dx.doi.org/doi:10.3989/mc.2012.01712.

15. Rickard, W.D.A.; Williams, R.; Temuujin, J.; van Riessen, A. (2011) Assessing the suitability of three Australian fly ashes as an aluminosilicate source for geopolymers in high temperature applications. Mater. Sci. Eng. A 528, 3390-3397. http://dx.doi.org/10.1016/j.msea.2011.01.005.

16. Rashad, A.M.; Bai, Y.; Basheer, P.A.M.; Collier, N.C.; Milestone, N.B. (2012) Chemical and mechanical stability of sodium sulfate activated slag after exposure to elevated temperature. Cem. Concr. Res. 42, 333-343. http://dx.doi. org/10.1016/j.cemconres. 2011.10.007.

17. Mejía de Gutiérrez, R.; Maldonado, J.; Gutiérrez, C. (2004) Resistencia a temperaturas elevadas de escoria activadas alcalinamente. Mater. Constr. 54, 87-92. http://dx.doi.org/ doi:10.3989/mc.2004.v54.i276.257

18. Guerrieri, M.; Sanjayan, J.; Collins, F. (2009) Residual compressive behavior of alkali-activated concrete exposed to elevated temperatures. Fire Mater. 33, 51-62. http://dx.doi.org/10.1002/fam.983.

19. Guerrieri, M.; Sanjayan, J.; Collins, F. (2010) Residual strength properties of sodium silicate alkali activated slag paste exposed to elevated temperatures. Mater. Struct. 43, 765-773. http://dx.doi.org/10.1617/s11527-009-9546-3.

20. Zuda, L.; Drchalová, J.; Rovnaník, P.; Bayer, P.; Keršner, Z.; Černý, R. (2010) Alkali-activated aluminosilicate composite with heat-resistant lightweight aggregates exposed to high temperatures: Mechanical and water transport properties. 
Cem. Concr. Compos. 32, 157-163. http://dx.doi.org/ 10.1016/j.cemconcomp.2009.11.009.

21. Zuda, L.; Cerný, R. (2009) Measurement of linear thermal expansion coefficient of alkali-activated aluminosilicate composites up to $1000^{\circ} \mathrm{C}$. Cem. Concr. Compos. 31,263-267. http://dx.doi.org/10.1016/j.cemconcomp.2009.02.002.

22. Rovnaník, P.; Bayer, P.; Rovnaníková, P. (2013) Characterization of alkali activated slag paste after exposure to high temperatures. Constr. Build. Mater. 47, 1479-1487. http://dx.doi.org/10.1016/j.conbuildmat.2013.06.070.

23. Živica, V. (2006) Effectiveness of new silica fume alkali activator. Cem. Concr. Compos. 28, 21-25. http://dx.doi.org/ 10.1016/j.cemconcomp.2005.07.004.

24. Živica, V. (2004) High effective silica fume alkali activator. Bull. Mater. Sci. 27, 179-182. http://dx.doi.org/ $10.1007 / \mathrm{bf02708502}$

25. Rouseková, I.; Bajza, A.; Živica, V. (1997) Silica fumebasic blast furnace slag systems activated by an alkali silica fume activator. Cem. Concr. Res. 27, 1825-1828. http:// dx.doi.org/10.1016/s0008-8846(97)00191-9.

26. Rodríguez, E.D.; Bernal, S.A.; Provis, J.L.; Paya, J.; Monzo, J.M.; Borrachero, M.V. (2013) Effect of nanosilica-based activators on the performance of an alkaliactivated fly ash binder. Cem. Concr. Compos. 35, 1-11. $\mathrm{http} / / / \mathrm{dx}$.doi.org/10.1016/j.cemconcomp.2012.08.025.

27. Mejía, J.M: Mejía de Gutiérrez, R. Puertas, F. (2013) Rice husk ash as a source of silica in alkali-activated fly ash and granulated blast furnace slag systems. Mater. Constr. 63, 361-375. http://dx.doi.org/10.3989/mc.2013.04712.

28. Bernal, S.A.; Rodríguez, E.D.; Mejía de Gutierrez, R.; Provis, J.L.; Delvasto, S. (2012) Activation of metakaolin/ slag blends using alkaline solutions based on chemically modified silica fume and rice husk ash. Waste Biomass Valoriz. 3, 99-108. http://dx.doi.org/10.1007/s10853-0115490-z.

29. Torres-Carrasco, M.; Palomo, J. G.; Puertas, F. (2014) Sodium Silicate from dissolution of glass wastes. Statistical analyses. Mater. Construcc. 64 [314]. http://dx.doi.org/ 10.3989/mc.2014.05213.

30. Salas, A.; Delvasto, S.; Mejía de Gutierrez, R.; Lange, D. (2009) Comparison of two processes for treating rice husk ash for use in high performance concrete. Cem. Concr. Res. 39, 773-778. http://dx.doi.org/10.1016/j.cemconres. 2009.05.006.
31. Bernal, S.A.; Provis, J.L.; Mejía de Gutierrez, R.; Rose, V. (2011) Evolution of binder structure in sodium silicateactivated slag-metakaolin blends. Cem. Concr. Compos. 33, 46-54. http://dx.doi.org/10.1016/j.cemconcomp.2010.09.004.

32. Yu, Q.; Sawayama, K.; Sugita, S.; Shoya, M.; Isojima, Y. (1999) The reaction between rice husk ash and $\mathrm{Ca}(\mathrm{OH})_{2}$ solution and the nature of its product. Cem. Concr. Res. 29, 37-43. http://dx.doi.org/10.1016/S0008-8846(98)00172-0.

33. Lee, W.K.W ; van Deventer, J.S.J. (2003) Use of infrared spectroscopy to study geopolymerization of heterogeneous amorphous aluminosilicates. Langmuir 19, 8726-8734. http://dx.doi.org/10.1021/la026127e.

34. Yu, P.; Kirkpatrick, R.J.; Poe, B.; McMillan, P.F.; Cong, X. (1999) Structure of calcium silicate hydrate (C-S-H): Near-, mid-, and far-infrared spectroscopy. J. Am. Ceram. Soc. 82 [3], 742-48. http://dx.doi.org/10.1111/j.1151-2916. 1999.tb01826.x

35. García Lodeiro, I.; Macphee, D.E.; Palomo, A.; Fernández-Jiménez, A. (2009) Effect of alkalis on fresh C-S-H gels. FTIR analysis. Cem. Concr. Res. 39, 147-153. http://dx.doi.org/10.1016/j.cemconres.2009.01.003.

36. García-Lodeiro, I.; Fernández-Jiménez, A.; Blanco, M.T.; Palomo, A. (2008) FTIR study of the sol-gel synthesis of cementitious gels: C-S-H and N-A-S-H. J. Sol-Gel. Sci. Technol. 45, 63-72. http://dx.doi.org/10.1007/s10971-0071643-6.

37. Reig, F.B.; Adelantado, J.V.G.; Moya Moreno, M.C.M. (2002) FTIR quantitative analysis of calcium carbonate (calcite) and silica (quartz) mixtures using the constant ratio method. Application to geological samples. Talanta 58, 811-821. http://dx.doi.org/10.1016/s0039-9140(02)00372-7.

38. Siriwardane, R.V.; Shen, M.-S.; Fisher, E.P.; Losch, J. (2005) Adsorption of $\mathrm{CO}_{2}$ on Zeolites at Moderate Temperatures. Energ. Fuel 19, 1153-1159. http://dx.doi. org/10.1021/ef040059h.

39. Stevens, R.W.; Siriwardane, R.V.; Logan, J. (2008) In situ Fourier transform infrared (FTIR) investigation of $\mathrm{CO}_{2}$ adsorption onto zeolite materials. Energ. Fuel 22, 3070-3079. http://dx.doi.org/10.1021/ef800209a.

40. Holmgren, A.; Wu, L.; Forsling, W. (1994) Surface hydration of aqueous calcium minerals as studied by Fourier transform Raman and infrared spectroscopy. Spectrochim. Acta, Part A 50, 1857-1869. http://dx.doi.org/10.1016/05848539(94)80198-3. 